\title{
PSIKOLOGI DAN KEPRIBADIAN \\ PERSPEKTIF AL-QURAN
}

\section{Oleh : Suparlan}

\begin{abstract}
Abstrak
- Psikologi modern lebih menitik beratkan kajian sosial dan budaya manusia tanpa memberi perhatian pengaruh spiritual manusia.Kajian psikologi yang demikian memiliki keterbatasan untuk mengungkap hajekat potensi psikologis manusia dan menjadi bias menentukan ke.pribadian manusia. Psikologi kepribadian perspektif Al-Quran perlu dikkaji dengan pertimbangan bahwa al-Qur'an adalah merupakan percikan dari kecerdasan Tuhan yang layak dijadikan sumber pedoman, tata nilai kehidupan bagi manusia. Al-Qur'an memberikan pandangan yang kompprehensif, bahwa manusia memiliki potensi bersifat fisik, jiwa, akal, hati dan ruh. Psikologi kepribadian Al-Qur'an adalah menekankan keseimbangan, yang terbentuk melalui dinamika tarik menarik antara dorongan potensi fisik dan potensi ruh, deengan pertimbangan hati, akal da nafs. Ada tida kelompok kepribadian menurut al-Quran: kepribadian imaro bis suu', lawwamah dan mutmainnah.
\end{abstract}

\section{A. PENDAHULUAN}

Sebagai disiplin ilmu hasil spekulasi pemikiran dan keterbasaan manusia, psikologi tentu memepunyai sejumlah kelemahan. Kelemahan psikologi dianntaramya dapat dilihat pada keterbatasan dalam menerangkan siapa sesungguhnya manusia, dan bagaimana seharusnya manusia menata dirinya meraih kesuksesan didalam menjalani ke hidupan. Psikologi sering sangat mereduksi pada fenomena-fenomena prilaku untuk melihat manusia. Dalam psikologi bahavior misalnya prilaku manusia sangat ditentukan oleh hukum stimulus dan respon. Dan psikoanalisis berkesimpulan bahwa manusia berprilaku hanya didorong oleh kebutuhan libidonya.

Melihat adanya kelemahan kajian psikologi, maka sangat perlu dikembangkan sudut pandang psikologi dari perspektif al-Qur'an. Penggunaan sudut pandang ini, dilakukan 
dengan pertimbangan bahwa al-Qur'an adalah merupakan percikan dari kecerdasan Tuhan yang layak dijadikan sumber pedoman, tata nilai kehidupan bagi manusia. Secara normatif alQur'an dapat digunakan sebagai sumber pokok Islam dalam merumuskan dan mengembangkan psikologi. Demikian juga dapat dimanfaatkan untuk menilai sundut pandang psikologi dalam melihat dan menilai konsep-konsep psikologi yang dapat dipertanggungjawabkan secara Qur'ani.

Sebagian ahli psikologi berpendapat bahawa psikologi telah menjadi sains yang kekurangan intipati utamanya. Psikologi Barat tidak mengkaji jiwa tetapi sebaliknya lebih memperhatikan kepada kajian tingkah laku semata-mata, demikian juga tidak membahas dengan dalam darimana asal dan bagaimana bentuk jiwa tidak dikaji oleh ahli psikologi barat. Tteori psikologi modern ciptaan sarjana-sarjana barat ini lebih menitik beratkan kajian sosial dan budaya manusia tanpa memberi perhatian pengaruh spiritual manusia.

Hassan Langgulung dalam tulisannya, Perspektif Baru dalam Perkembangan Psikologi Moden, sumumbangan Islam, menyatakan bahawa pskologi Islam merujuk kepada empat istilah yaitu 'aql', 'nafs', 'roh' dan 'qalb'. Inilah perbedaan paling kentara antara psikologi barat dan psikologi Islam, kajian terhadap jiwa diutamakan sedangkan di barat, kajian terhadap tingkah laku lebih diutamakan.

Dengan demikian perlu ada kajian terhadap al-qur'an, khususnya adalah ayat-ayat yang erat dengan psikologi. Dengan harapan memunculkan perspektif baru dalam psikologi dibawah pengaruh Al-Quran, yang akan mengisi kekurangan psikologi untuk kebaikan manusia dan masyarakat. Pengajian jiwa manusia merupakan aktiviti saintifik yang berguna dan patut digalakkan sebagaimana ilmu pengetahuan yang lain. Penyelidikan mengenai diri manusia ternyata jalan yang paling singkat dan paling pasti adalah melalui pengkajian al- 
Qur'an, hal ini sejalan dengan penegasan yang tertuang dalam QS Al-Fusilat : 53 : “Kami akan memperlihatkan kepada mereka tanda-tanda (kekuasaan) Kami di segenap penjuru \& pada diri mereka sendiri, sehingga jelaslah bagi mereka bahawa Al-Quran itu adalah benar". Dan QS : Al-Dzariyat : 56 “Dan di bumi ini terdapat tanda-tanda (kekuasaan Allah) bagi orang- orang yang yakin, dan (juga) pada dirimu sendiri" Hujah ini menguatkan keperluan untuk mengintegrasikan kandungan al-Quran dengan ilmu psikologi moden bagi memberikan roh kepada bidang ini.

\section{B. POTENSI PSIKOLOGI MANUSIA}

Sampai penghujung abad XX , tedapat empat aliran besar psikologi yakni, psychoanalysis, behavior psychology, humanistic psykhology, dan transpersonal psychology (Bastaman,1997:49). Masing- masing aliran meninjau manusia dari sudut pandang yang berlainan. Menurut Psikoanalisis, kepribadian manusia terdiri dari tiga potensi yaitu ; Id (dorongan -dorongan biologis ), Ego ( Kesadaran terhadap realitas kehidupan), Super ego ( kesadaran normatif). Ketiga ini saling berinteraksi satu sama lain dengan fungsi masingmasing yang khas.

Berbeda dengan psikoanalisis, yang menggambarkan bahwa tak disadari dorongan nafsu-nafsu rendah banyak menentukan prilaku manusia, aliran menunjukan bahwa upaya rekayasa dan kondisi lingkungan luar adalah hal yangh paling mempengaruhi dan menentukan kepribadian manusia. Melalui eksperimen terhadapnya digunakan untuk mengetahui pola dasar prilaku manusia dan proses perubahannya. Kepribadian manusia terbentuk dengan upaya menstimulus dengan disertai dengan penguatan dengan cara 
memberikan hadiah, yang selanjutnya dibiasakan sehingga ahirnya merespon semua stimulus untuk selanjutnya sampai terbentuk kepribadian ( Nawawi,2000: 54-56).

Sedang psikologi humanistik memandang manusia memiliki potensi-potensi baik, minimal lebih banyak baiknya dari pada kecenderungan buruknya. Psikologi ini memusatkan perhatian untuk menelaah kualitas manusia, yakni sifat dan kemampuan yang terpatri pada eksistensi manusia. Kemampuan potensiil manusia yakni, kemampuan abstraksi, daya analisis dan sisntesis, imajinasi, kreatifitas, kebebasan berkehendak, bertanggungjawab, aktualisasi diri, makna hidup, sikap etis dan estetik. Kemampuan-kemampuan ini khas insani, yang tidak dimiliki oleh makhluk lain seperti hewan (Bastaman,1997: 52).

Al-Qu'an memandang manusia sebagai makhluk Alah swt. yang memiliki keunikan tertentu. Manusia diciptakan dengan bentuk raga yang sebaik-baiknya ( Q S : $95: 4$ ), serta dilengkapi dengan organ psikofisik yang istimewa. Dalam beberapa ayat berikut al-Quran secara gamblang menegaskan manusia memiliki potensi- potensi psikofikk ; kekuatan fisi, nafs, akal, hati dan ruh .

-9: ثمّ سوه و نفخ فيه من روحه وجعل لكم السمع و الابصار و الافئدة قليلا ما تشكرون (السجدة “Kemudian Dia menyempurnakan dan meniupkan ke dalamnya roh (ciptaan)-Nya dan Dia menjadikan bagi kamu pendengaran, penglihatan dan hati; (tetapi) kamu sedikit sekali bersyukur ( As-Sajdah : 9)

و الله اخرجكم من بطون امّهاتكم لا تعلمون شيئا وجعل لكم السمع والابصار و الاافئدة لعلّكم تشكرون( النحل : 78) 
"Dan Allah mengeluarkan kamu dari perut ibumu dalam keadaan tidak mengetahui sesuatupun, dan Dia memberi kamu pendengaran, penglihatan dan hati, agar kamu bersyukur (An-Nahl : 78)”.

$$
\text { و قالو الو كنّا نسمع او نعقل ما كنّا في اصحب السعير. }
$$

"Dan mereka berkata: "Sekiranya kami mendengarkan atau memikirkan (peringatan itu) niscaya tidaklah kami termasuk penghuni-penghuni neraka yang menyala-nyala (Al-Mulk: 10)."

Potensi fisik yang dimiliki manusia yang yang secara organ fisiknya telah terbentuk semrpurna sejak dalam kandungan usia empat bulan, adalah merupakan kekuatan yang dapat digunakan sebagai alat untuk merealisasikan dorongan fisik sekaligus untuk membantu memenuhi dorongan psikisnya. Sedangkan jiwa/ nafs disamping sebagai perwujudan keakuan manusia juga sebaga potensi yang terkait dengan memunculkan dorongan insting berkehendak dan berimajinasi. Akal adalah merupakan kemampuan yang luar biasa dalam diri manusia, yang dapat digunakan untuk menalar dan menilai secara rasional untuk membedakan benar - salah serta baik atau buruk. Potensi hati pada tingkatan paling rendah memang dapat mengarah pada baik atau buruk, namun pada tingkatan hati yang tinggi ( qolbun salim ), adalah menjadi pencerah akal, jiwa dan fisik untuk terus mengikuti pada nilai- nilai kebenaran. Hati adalah menejernya manusia, dialah yang akan menentukan/ memenej prilaku mengarahkan kepada kebaikan dan bisa sebaliknya. Dalam Hadis ditegaskan bahwa :

$$
\text { : (ألا و إن في الجسد مضغة إذا صلحت صلح الجسد كله، وإذا فسدت فسد الجسد كله، ألا وهي }
$$

(القب)() 
Sedangkan ruh yang telah dinafkhahkan sejak manusia masih ada dalam kandungan adalah merupakan potensi yang sangat tinggi, ketinggian ruh seperti pada surat as-Sajdah yang dapat dimaknai merupakan potensi dzat Ketuhanan, demikian juga dikaitkan bahwa ruh adalah merupakan urusan Tuhan ( al-Isro :175). Potensi ruh dari persepsi ini berarti merupakan kekuatan yang diberikan oleh Allah swt. Agar manusia dapat menjadi khalifah dengan meneladani sisifat-sifat Allah swt. dan diberi potensi agar sepenuhnya dapat mengikuti aturan Nya dalam Islam.

Kepribadian dan prilaku manusia akat terbentuk dari interaksi antar potensi, ketika dalam proses interaksi yang lebih dominan adalah orientasi pada pemenuhan kebutuhan fisik dan mengabaikan akal, hati dan ruh maka manusia akan jatuh derajatnya menjadi sama dengan hewan ( Q.S al-A'raf : 189), dan sebaliknya jika manusia mengabaikan kebutuhan fisik hanya memenuhi kebutuhan ruh, manusia menjadi menyerupai dengan tabiat malaikat. Oleh karenan itu kemampuan jiwa, akal, dan hati harus bekerja keras untuk dapat menyeimbangkan dua potensi fisik yang cenderung mengarah pada kesenangan materiil dengan potensi ruh yang lebih mendorong pada kedekatan dengan tuhan, serta mengikuti ketunddukan penuh pada kebaikan dari ajaran Allah swt. Dengan demikian maka potensipoptensi yang sangat indah ini baru akan maksimal menggantarkan manusia menjadi manusiawi kalau potensi itu diseimbangkan dengan secara proporsional. Diagram dibawah ini dapat memberi gambaran beda manusia dengan hewan dan malaikat : 


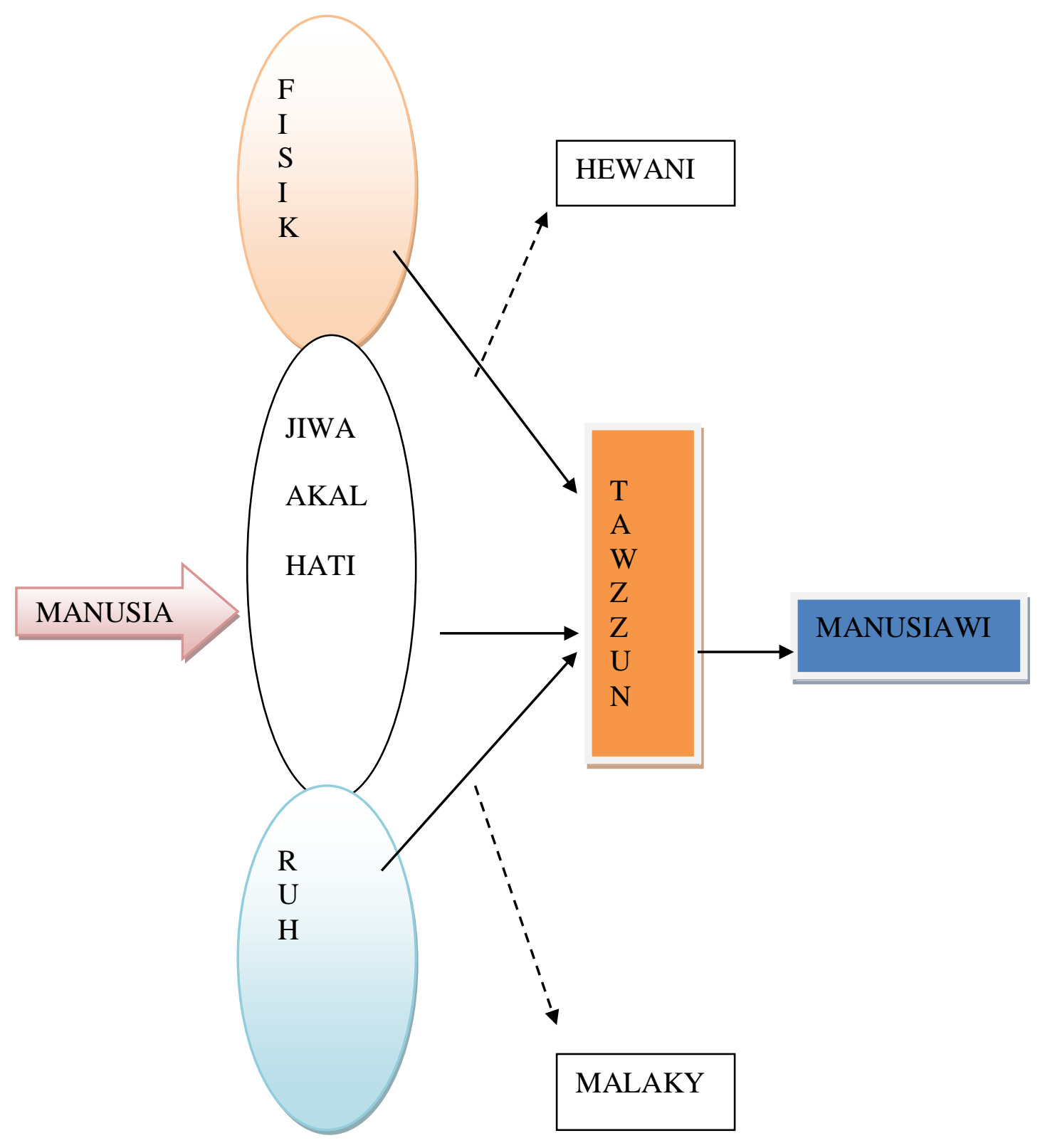

Pandangan al-Qur'an terhadap manusia bukan hanya memperhatikan potensi batin, sebagaimana tegambar pada diagram di atas, melainkan al-Quran juga sangat memperhatikan betapa besar pengaruh lingkungan dan pendidikan, Pada surat Al- 
Baqoroh :31 jelas ditegaskan bahawa Allah swt mengajarkan nama-nama, yang dengan kata lain manusia adalah juga mahluk yang dapat dikenai pendidikan. Dan pada Hadis yang sangat populer dijelaskan : Semua anak Adam dilahirkan dalam kondisi fitroh, maka kedua orang tuanyalah yeng menjadikan anak menjadi yahudi atau nasroni. Dan yang paling sepesifik al-Qur'an telah menjawab misteri ilmuan psikolog yang mencaricari kekuatan tranpersonal dengan menunjukan potensi ruh yang ada dalam diri manusia.

\section{B. KEPRIBADIAN MANUSIA}

Dalam prilaku psikologi al-Qur'an, manusia terkandng bisa terjatuh pada siafatsifat hewan, dan atau berubah seperti sifat-sifat malaikat .Adakalanya, manusia tertarik oleh kebutuhan dan syahwat tubuhnya, dan adakalanya ia tertarik oleh kebutuhan spiritualnya. Al-Qur'an mengisyaratkan pergulatan psikologis yang dialami oleh manusia, yakni antara kecenderungan pada kesenangan-kesenangan jasmani dan kecenderungan pada godaan-godaan kehidupan duniawi. Jadi, sangat alamiah bahwa pembawaan manusia tersebut terkandung adanya pergulatan antara kebaikan dan keburukan, antara keutamaan dan kehinaan, dan lain sebagainya. Untuk mengatasi pergulatan antara aspek material dan aspek spiritual pada manusia tersebut dibutuhkan solusi yang baik, yakni dengan menciptakan keselarasan di antara keduanya.

Disamping itu, Al-Qur'an juga mengisyaratkan bahwa manusia berpotensi positif dan negatif, pada hakikatnya potensi positif manusia lebih kuat daripada potensi negatifnya. Hanya saja daya tarik keburukan lebih kuat dibanding daya tarik kebaikan. Potensi positif dan negatif manusia ini banyak diungkap oleh Al-Qur'an. Di antaranya ada dua ayat yang menyebutkan potensi positif manusia, yaitu Surah at-Tin [95] ayat 5 
(manusia diciptakan dalam bentuk dan keadaan yang sebaik-baiknya) dan Surah al-Isra' [7] ayat 70 (manusia dimuliakan oleh Allah dibandingkan dengan kebanyakan makhlukmakhluk yang lain). Di samping itu, banyak juga ayat Al-Qur'an yang mencela manusia dan memberikan cap negatif terhadap manusia. Di antaranya adalah manusia amat aniaya serta mengingkari nikmat (Q.S. Ibrahim [14]: 34), manusia sangat banyak membantah (Q.S. al-Kahfi [18]: 54), dan manusia bersifat keluh kesah lagi kikir (Q.S. al-Ma'arij [70]: 19)

Sebenarnya, dua potensi manusia yang saling bertolak belakang ini diakibatkan oleh persatruan di antara tiga macam nafsu, yaitu nafsu ammarah bi as-suu' (jiwa yang selalu menyuruh kepada keburukan), lihat Surah Yusuf [12] ayat 53; nafsu lawwamah (jiwa yang amat mencela), lihat Surah al-Qiyamah [75] ayat 1-2; dan nafsu muthma'innah (jiwa yang tenteram), lihat Surah al-Fajr [89] ayat 27-30. Konsepsi dari ketiga nafsu tersebut merupakan beberapa kondisi yang berbeda yang menjadi sifat suatu jiwa di tengah-tengah pergulatan psikologis antara aspek material dan aspek spiritual (Najati,1985:377).

Nafsul imaro 'bissu', dilihat dari potensi manusia adalah akan terjadi ketika manusia didominasi oleh nafsu yang mengarah pada pemenuhan kebutuhan fisik, yakni ketika dorongan spiritual dikalahkan oleh dorongan fisik. Dan nafsul mutmainnah, adalah terbentuk ketika dorongan fisik mampu disembangkan oleh jiwa akal dan hati dengan kekuatan spiritual/ruh. Sedangkan nafsul lawwamah, terbentuk ketika antara kekuatan fisik dan kekuatan ruh saling mendominasi dalam kondisi dan waktu yang berbeda.

Menurut Usman Najati ( Najati,1985: 387-389) , pola kepribadian manusia dikelompokkan berdasar pada al-Qur'an sebagai berikut :

\section{a. Kepribadian Orang Beriman (Mu'minun)}


Kepribadian orang beriman akan dapat tercapai bila diawali dewngan percaya pada rukun iman yang terdiri atas iman kepada Allah swt., iman kepada para malaikatNya, iman kepada Kitab-kitab-Nya, iman kepada para rasul-Nya, percaya pada Hari Akhir, dan percaya pada ketentuan Allah (qadar/takdir). Keimanan yang kuat terhadap rukun iman tersebut akan membentuk nilai-nilai yang melandasi seluruh aktivitasnya. Dengan nilai-nilai itu, setiap individu akan dapat terbentu/ memiliki kepribadian yang lurus dan sehat. Orang yang memiliki kepribadian lurus dan sehat ini memiliki ciri-ciri antara lain:Akan bersikap moderat dalam segala aspek kehidupan,Rendah hati di hadapan Allah dan juga terhadap sesama manusia,Senang menuntut ilmu,Sabar, dan Jujur.

Gambaran manusia mukmin dengan segenap ciri yang terdapat dalam Al-Qur'an ini merupakan gambaran insan kamil dalam kehidupan ini, dalam batas yang mungkin dicapai oleh manusia. Allah menghendaki agar manusia dapat berusaha mewujudkannya dalam diri nya. Rasulullah saw. telah membina generasi pertama kaum mukminin atas dasar ciri-ciri tersebut. Beliau berhasil mengubah kepribadian mereka secara total serta membentuk mereka sebagai mukmin sejati yang mampu mengubah wajah sejarah dengan kekuatan pribadi dan kemuliaan akhlak mereka. Singkatnya, kepribadian orang beriman dapat menjadi teladan bagi orang lain.

\section{b. Kepribadian Orang Kafir (Kafirun)}

Ciri-ciri orang kafir yang diungkapkan dalam Al-Qur'an antara lain:Suka putus asa,Tidak menikmati kedamaian dan ketenteraman dalam kehidupannya,Tidak percaya pada rukun iman yang selama ini menjadi pedoman keyakinan umat Islam, Mereka tidak mau mendengar dan berpikir tentang kebenaran yang diyakini kaum Muslim, Mereka sering tidak 
setia pada janji, bersikap sombong, suka dengki, cenderung memusuhi orang-orang beriman, Mereka suka kehidupan hedonis, kehidupan yang serba berlandaskan hal-hal yang bersifat material. Tujuan hidup mereka hanya kesuksesan duniawi, sehingga sering kali berakibat ketidakseimbangan pada kepribadian, Mereka pun tertutup pada pengetahuan ketauhidan, dan lain-lain.

Ciri-ciri orang kafir sebagaimana yang tergambar dalam Al-Qur'an tersebut menyebabkan mereka kehilangan keseimbangan kepribadian, yang akibatnya mereka mengalami penyimpangan ke arah pemuasan syahwat serta kesenangan lahiriah dan duniawi. Hal ini membuat mereka kehilangan satu tujuan tertentu dalam kehidupan, yaitu beribadah kepada Allah dan mengharap rida-Nya untuk mengharap magfirah serta pahala-Nya di dunia dan akhirat.

\section{c. Kepribadian Orang Munafik (Munafiqun)}

Munafik adalah segolongan orang yang berkepribadian sangat lemah dan bimbang. Di antara sifat atau watak orang munafik yang tergambar dalam Al-Qur'an antara lain:Mereka "lupa" dan menuhankan sesuatu atau seseorang selain Allah swt., Dalam berbicara mereka suka berdusta, Mereka menutup pendengaran, penglihatan, dan perasaannya dari kebenaran, Orang-orang munafik ialah kelompok manusia dengan kepribadian yang lemah, peragu, dan tidak mempunyai sikap yang tegas dalam masalah keimanan. Mereka bersifat hipokrit, yakni sombong, angkuh, dan cepat berputus asa. 
Ciri kepribadian orang munafik yang paling mendasar adalah kebimbangannya antara keimanan dan kekafiran serta ketidakmampuannya membuat sikap yang tegas dan jelas berkaitan dengan keyakinan bertauhid.

Dengan demikian, umat Islam sangat beruntung mendapatkan rujukan yang paling benar tentang kepribadian dibanding teori-teori lainnya, terutama diyakini rujukan tersebut adalah wahyu dari Allah swt. yang disampaikan kepada Nabi Muhammad saw., manusia teladan kekasih Allah. Oleh karena itu pula, Nabi Muhammad saw. diutus oleh Allah swt. ke muka bumi untuk memainkan peran sebagai model insan kamil bagi umat manusia. Kepribadian dalam kehidupan sehari-hari mengandung sifat-sifat manusiawi kita, alam pikiran, emosi, bagian interior kita yang berkembang melalui interaksi indra-indra fisik dengan lingkungan. Namun lebih dalam lagi, kepribadian sesungguhnya merupakan produk kondisi jiwa (nafs) kita yang saling berhubungan. Atau, dapat dikatakan pula bahwa kepribadian seseorang berbanding lurus dengan kondisi jiwanya (nafs).

\section{KESEIMBANGAN DALAM KEPRIBADIAN}

Solusi ideal terhadap konflik jasmani dan ruhani dalam diri manusia adalah menyeimbangkan keduanya. Sebab, di satu sisi manusia membutuhkan pemenuhan kebutuhan jasmani dalam batas-batas yang diperbolehkan syariat Islam, dan di sisi lain manusia dituntut untuk memenuhi kebutuhan ruhani. Penyeimbangan keduanya merupakan hal yang mungkin dilakukan jika manusia konsisten dalam pola kehidupan yang wajar, yakni mengutamakan sikap tengah, tidak berat sebelah dan dan ekstrim pada salah satu tuntutan tersebut.

Kemampuan manusia untuk dapat menyeimbangkan kepribadian sangat dipengaruhi oleh kemampuan hati, akal, dan nafs. Ketika hati mnusia dalam kondisi sehat/ qolbun salim 
akan dapat dengan mudah menangkap keuatan ruh yang mendorong pada kebaikan. Kemampuan hati akan lebih terarah jika akal manusiapun dapat bekerja dengan perimbangan matang kecerdasan spiritual, emosional dan logika intelgen yang benar. Dengan hati yang sehat dan akal yang benar maka otematis akan dapat mengendalikan dorongan nafs untuk mengarah pada kebaikan prilaku dan dapat memenej kebutuhan fisik berdasar dorongan ruhiah,

Kepribadian yang berkeseimbangan, merupakan 1 sikap tengah. Sikap tengah juga dapat dijadikan sebagai metode merealisasikan keseimbangan antara dua dimensi dalam diri manusia, yakni: material dan spiritua ( Mursi, 1997:61-62). Al-Qur'an menunjukkan perlunya merealisasikan keseimbangan ini, sebagaimana firman Allah :

"Dan carilah pada apa yang telah dianugerahkan Allah kepadamu (kebahagiaan) negeri akhirat, dan janganlah kamu melupakan bagianmu dari (kenikmatan) duniawi." (AlQashash: 77)

Dalam pengertian ini pula Rasulullah saw. Bersabda :

"Bukankah sebaik-baik kamu orang yang bekerja untuk dunianya saja tanpa akhiratnya, dan tidak pula orang yang bekerja untuk akhiratnya saja dan meninggalkan dunianya. Dan sesungguhnya sebaik-baik kamu adalah orang yang bekerja untuk ini (akhirat) dan ini (dunia).”

Mengenai sikap pertengahan dan adil, Allah berfirman:

"Dan demikian (pula) Kami telah menjadikan kamu (umat islam), umat yang adil dan pilihan agar kamu menjadi saksi atas (perbuatan) manusia dan agar Rasul (Muhammad) menjadi saksi atas (perbuatan) kamu." (Al-Baqarah: 143) 
"Dan orang-orang yang apabila membelanjakan (harta), mereka tidak berlebihlebihan, dan tidak (pula) kikir, dan adalah (pembelanjaan) itu di tengah-tengah antara yang demikian." (Al-Furqan: 67)

"Hai anak adam, pakailah pakaianmu yang indah di setiap (memasuki) masjid, makan dan minumlah, dan janganlah berlebih-lebihan. Sesungguhnya Allah tidak menyukai orangorang yang berlebih-lebihan." (Al-A'raf: 31)

"Dan janganlah kamu mengeraskan suaramu dalam shalatmu dan janganlah pula merendahkannya. Dan carilah jalan tengah diantara keduanya." (Al-Isra: 110)

Rasulullah saw.bersabda:

"Sebaik-baik perkara adalah pertengahannya." (HR.Al-Baihaqi)

Prinsip keseimbangan merupakan konsep yang harus diperhatikan oleh manusia. Prinsip ini dengan tegas menekankan, bahwa kepribadian yang dikonsepkan al-Qur'an sangat memperhatikan aspek prilaku lahiriaah yang didorong oleh keseimbangan interaksi dua sisi potensi fisik dengan potensi batiniyah berupa ruhiyah. Dengan harapan agar semua prilaku manusia apapun jenisnya, adalah bentuk prilaku yang kalau dilakukan disamping berdasar pertimbangan keseimbangan proporsional seluruh potensi manusiawinya ( fisik, akal, jiwa, hati dan ruh ). Dan dalam hal ini maka kepribadian Qur'ani adalah kepribadian yang kalau dipraktekkan akan mengantarkan pada perbuatan yang disamping menyehatkan potensi manusiawi secara proporsional, serta tidap ada sedikitpun menyakiti atau mematikan potensi diri dan orang lain.

\section{PENUTUP}


Penulis menyadari, kajian psikologi adalah kajian yang membutuhkan kedalaman dan melalui berbagai pendekatan, oleh karena itu pastilah kajian ini masih kajian awal yang perlu dilengkapi dengan data dan fakta sekaligus analisis komprehensif. Karena ini baru kajian awal, maka saran dan kritik sengat diharapkan, untuk membuka wawasan lebih detail dan komprehensif dan mengarahkan pada perumuran psikologi dan kepribadian yang lebih baik.

Setidaknya dari kajian awal ada beberapa yang perlu disimpulkan, yaitu :

1. Manusia menurut al-Qur'an, memiliki potensi-potensi yang lebih komprehensif ( fisik,jiwa, akal, hati dan ruh ).

2. Psikologi al-Qur'an, dengan demikian memandang prilaku manusia ditentukan oleh interaksi keseimbangan potensi manusiawi.

3. Keseimbangan potensi manusiawiakan mengantarkan manusia berkepribadiaan baik, dan sebalinya jika ketidak ada keseimbangan akan mengakibatkan derajat kepribadian menjadi berubah adakalanya lawwamah, atau bisa juga jadi imaro’ bissu'.

4. Pola kepribadian manusia dapat dibagi tiga, kepribadian yang mutmainnah, kepribadian lawwamah, dan imaro' bissu'. 


\section{DAFTAR BACAAN}

Ancok, Djamaludin dan Fuad Nasution Suroso, Psikologi Islami Solusi Islam atasProblem Psikologi, Yogyakarta : Pustaka Pelajar, 1995

Avery, John dan Hasan Askari, Menuju Humanisasi Spiritual, Surabaya : Risalah Gusti, 1991

Bastaman,Hana Djumhana, Integrasi Psikologi dengan Islam Menuju Psikologi Islami, Yogyakata : Pustaka Pelajar, 1997

Departemen Agama RI,Al-Qur'an dan Terjemahnya, Semarang : Toha Putra, T.th

Nawawi,Rifaat Syauqi, dkk.,Metodologi Psikologi Islami, Yogyakarta, Pustaka Pelajar, 2000

Mursi, Abdul Hamid, SDM Yang Produktif Pendekatan Al-Qur'an dan Sains, Jakarta : Gema Insani Pres, 1997

Sukanto, Nafsiologi Suatu Pendekatan Alternatif Atas Psikologi,Jakarta : Integritas Press,

www.PA-IN face book, didownload, 23 0ktober 2010 